\title{
Multifunctional central pattern generator controlling walking and paw shaking
}

\author{
Brian Bondy ${ }^{1}$, Alexander Klishko², Boris Prilutsky² $^{2}$ Gennady Cymbalyuk ${ }^{1 *}$ \\ From The Twenty Third Annual Computational Neuroscience Meeting: CNS*2014 \\ Québec City, Canada. 26-31 July 2014
}

Central pattern generators (CPGs) are oscillatory neuronal networks controlling rhythmic motor tasks such as breathing and walking. A multifunctional CPG can produce multiple patterns, e.g. patterns with different periods [1-5]. Here, we investigate whether a pair of cat behaviors - walking and paw shaking - could be controlled by a single multifunctional CPG exhibiting multistability of oscillatory regimes. In experiments, both behaviors can be elicited in a spinalized cat, and there is evidence that the same circuitry is used for both rhythms $[2,3]$. We present a parsimonious model of a half-center oscillator composed of two mutually inhibitory neurons. These cells contains two slowly inactivating inward currents, a persistent $\mathrm{Na}^{+}$current $\left(\mathrm{I}_{\mathrm{NaP}}\right)$ and a low voltage activated $\mathrm{Ca}^{++}$current $\left(\mathrm{I}_{\text {CaLVA }}\right)$. The dynamics of the multifunctional CPG is based on that the $\mathrm{I}_{\mathrm{CaLVA}}$ inactivates much slower than $\mathrm{I}_{\mathrm{NaP}}$ and at the more hyperpolarized membrane potentials. Here, we demonstrate the co-existence of two rhythms (Figure 1). At first, the model demonstrates walking pattern. A switch from a slow, 1-2 $\mathrm{Hz}$ walking rhythm to fast, 7-10 Hz paw shake rhythm was elicited by a pulse of conductance of excitatory current delivered to extensor and flexor neurons. Then, a switch back to walking was triggered by a shorter pulse of conductance of inhibitory current delivered to the extensor neuron.
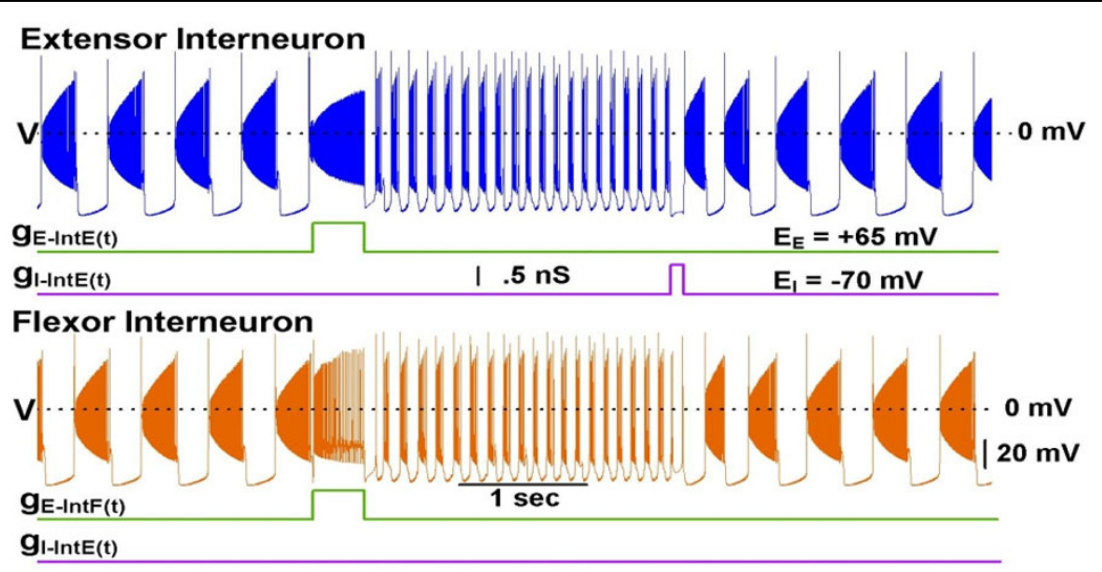

Figure 1 Two mutually inhibitory interneurons, IntE (Extensor Interneuron) and IntF (Flexor Interneuron) produce alternating bursting activity at approximately $1.6 \mathrm{~Hz}$ representing walking pattern. A switch to paw shaking is executed by a pulse of excitatory conductance delivered to both cells for 1 second. The paw shake rhythm is represented by a $9 \mathrm{~Hz}$ bursting regime. An inhibitory conductance activated for .1 second in IntF causes a large rebound burst and a fast transition back to the walking rhythm.

\footnotetext{
* Correspondence: gcymbalyuk@gsu.edu

${ }^{1}$ Neuroscience Institute, Georgia State University, Atlanta, Georgia, 30302,

USA

Full list of author information is available at the end of the article
} 
The CPG model was also incorporated into a neuromechanical model of a cat hindlimb in the AnimatLab environment [6]. The model provides a cellular mechanism of multifunctional CPG operation.

\section{Acknowledgments}

The authors acknowledge support by the NSF PHY-0750456 to Gennady Cymbalyuk and by NIH P01 HD32571, R01 EB012855, and R01 NS048844 and by the Center for Human Movement Studies at GATech to Boris Prilutsky.

\section{Authors' details}

'Neuroscience Institute, Georgia State University, Atlanta, Georgia, 30302,

USA. ${ }^{2}$ School of Applied Physiology, Georgia Institute of Technology, Atlanta, Georgia, 30332, USA.

Published: 21 July 2014

\section{References}

1. Berkowitz A: Both shared and specialized spinal circuitry for scratching and swimming in turtles. J Comp Physiol A 2002, 188(3):225-234.

2. Carter MC, Smith JL: Simultaneous control of two rhythmical behaviors. II. Hindlimb walking with paw-shake response in spinal cat. J of Neurophysiol 1986, 56(1):184-195.

3. Frigon A, Gossard JP: Evidence for specialized rhythm-generating mechanisms in the adult mammalian spinal cord. J of Neurosci 2010, 30(20):7061-7071.

4. Venugopal S, Travers J, Terman D: A computational model for motor pattern switching between taste-induced ingestion and rejection oromotor behaviors. J Comput Neurosci 2007, 22(2):223-238.

5. Manor Y, Nadim F: Synaptic depression mediates bistability in neuronal networks with recurrent inhibitory connectivity. J Neurosci 2001, 21(23):9460-9470.

6. Klishko AN, Cofer D, Cymbalyuk G, Edwards DH, Prilutsky BI: Paw-shake response and locomotion: can one CPG generate two different rhythmic behaviors? BMC Neuroscience 2012, 13(Suppl 1):P70.

\section{doi:10.1186/1471-2202-15-S1-P181}

Cite this article as: Bondy et al:: Multifunctional central pattern generator controlling walking and paw shaking. BMC Neuroscience 2014 15(Suppl 1):P181.

\section{Submit your next manuscript to BioMed Central and take full advantage of:}

- Convenient online submission

- Thorough peer review

- No space constraints or color figure charges

- Immediate publication on acceptance

- Inclusion in PubMed, CAS, Scopus and Google Scholar

- Research which is freely available for redistribution

Submit your manuscript at www.biomedcentral.com/submit
Biomed Central 